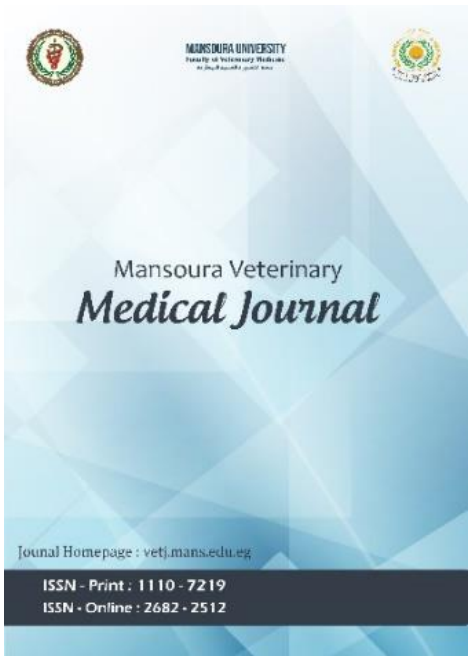

\title{
Prevalence and potential risk factors associated with methicillin resistant Staphylococcus aureus infection in Dairy farms
}

Mohamed El-Fateh, Adel El-Gohary, Mona Elsayed, Fatma ElGohary

To cite this article: Mohamed El-Fateh, Adel El-Gohary, Mona Elsayed, Fatma El-Gohary. Prevalence and potential risk factors associated with methicillin resistant Staphylococcus aureus infection in Dairy farms. Mansoura Veterinary Medical Journal 2020; 21, 2: 39-47.

To link to this article: https://doi.org/10.35943/mvmj.2020.21.2.0204

Published online: 25 June 2020

Submit your article to this journal

CrossMark data 


\title{
Prevalence and potential risk factors associated with methicillin resistant Staphylococcus aureusinfection in Dairy farms
}

\author{
Mohamed El-Fateh, Adel El-Gohary, Mona El sayed, Fatma El-Gohary*
}

Department of Hygiene and Zoonoses, Mansoura University, 35516, Egypt

ARTICLE HISTORY
Received: 16.02 .2020
Revised: 06.04.2020
Accepted: 16.05.2020
Address correspondence to Fatma El-
Gohary; Tel: +201097070169; Fax: +20
(50) 2202253; E-mail:
dr.fatmagohary@gmail.com

ABSTRACT

\begin{abstract}
Objective: A cross sectional study was conducted between June 2017 and August 2018 in around Dakahlia governorate to identify Methicillin resistant Staphylococcus aureus (MRSA) and to determine risk factors associated with the occurrence of mastitis in dairy cows.

Design: Cross sectional study

Animals and samples: 130 dairy cattle ( 744 samples) and 181 environmental samples ( 36 bedding, 37 bulk tank milk BTM, 27 feed troughs, 27 water troughs, 27 milk linear and 27 worker's nasal swabs), with a total of 925 samples were studied.

Procedures: Three hundred and seventy-two quarters were examined to detect clinical and subclinical mastitis by physical examinations and California mastitis test. In addition, bacteriological isolation and identification of Staphylococcus aureus and MRSA were carried on the above milk samples of above mentioned quarters, teat swabs and environmental samples.

Results: The overall prevalence of Staphylococcus aureus and MRSA was 59.4 and 22.4, respectively. The MRSA were more prevalent in mastitic quarter $\left(X_{2}=31.146\right.$, $P$-value $\left.=0.000\right)$, Holstein Friesian breed $(P$ value $=0.021)$, Old aged dairy cattle $(>8$ years $)(P$-value $=0.000)$, Multiparous cows $(P$-value $=0.000)$, large herd size $(>=2000)(P$-value $=0.000)$.

Conclusion and clinical relevance: The present result indicates that MRSA is a major cause of mastitis in dairy farms at northern Egypt, where one of the key elements for controlling its spreading depends mainly on determining its potential risk factors responsible for its existence.
\end{abstract}

Keywords: Methicillin-resistant Staphylococcus aureus (MRSA), Risk factors, Antibiotic

resistance, Dairy farms

\section{INTRODUCTION}

Mastitis is considered the most influencing disease in dairy sector, as it leads to massive losses in milk,culling and even death of infected cattle [1]. Staphylococcus aureus is one of the most crucial contagious mastitis pathogens in the dairy cattle [2]. S. aureus infection is es timated to be pres ent in up to $90 \%$ of dairy farms with $35 \%$ of the economic loss in the dairy industry [3].

Antibiotics are utilized for both therapeutic and subtherapeutic purposes in veterinary practice. Subtherapeutically, antimicrobials are used to enhance feed efficiency and promote growth of a nimals [4]. Currently, There is increased public and scientific concern regarding extensive use of antimicrobials for therapeutic or sub-therapeutic purposes, due to the emergence and dissemination of multiple antibiotic resistant zoonotic bacterial pathogens [5]. Data from the USDA Na tional Animal Health Monitoring System indicated that the main percent of farms that treated cows with a ntibiotic were for treatment of mastitis by rate of $85.4 \%$ [6].

High-level resistance of Staphylococcus aureus to $\beta$ lactams is acquired bya mecA gene coding, a modified penicillin binding protein (PBP2a) was first observed in the early 1960's
[7]. For effective trea tment and control of bovine mastitis, it is crucial to study the antimicrobial resistance mechanism and epidemiology of Staphylococcus aureus infections [8].

MRSA is frequently transmitted via environmental contamination; reaching the environment through animal manure and then it could be carried by air. There is an actual hazard of MRSA spreading from a nimal manure conta minating water courses and agriculture crops [9]. The age progression and high delivery rate ( $>7$ calves) induce 13 times greater risk of IMI than lower delivery calving rate ( 3 calves), which could be related to calving influences on teat muscle relaxation and enlargement making udder much ea sier accessible to infection [10]. Due to the contagious character of MRSA that shed in milk during milking which becomes a source of infection to other healthy cows. Consequently, large herd size farms characterized by high risk of exposure to infection due to increased stocking density [11]. Interestingly, cross breeds are more susceptible to be infected by Staphylococcus aureus mastitis than local breeds, due to physiological and anatomical character difference of mammary gland and quantity of milk produced by cow. Besides, high milk production is related to 
genetic selection, lead to increased genetic sensitivity to mastitis [12]. Therefore, Knowledge of MRSA is necessary to make deci sions regarding antibiotic treatment and prerequisite for es tablishing control strategies in the area. This study aimed to investigate the prevalence of Methicillin-resistant Staphylococcus aureus and to assess the potential risk factors associated such infection in dairy farms at northern Egypt.

\section{MATERIALS AND METHODS}

\subsection{Study area and design}

The study was conducted at Dakahlia governorate which located northeast of Cairo $31.0832^{\circ}$ latitude, $31.4913^{\circ}$ Iongitude. Dakahlia has a mild climate that tends to be warm in winter with some rain that increases on the coasts, and is hot in summer; where the average annual temperatures range from 14 - 28 degrees Cel sius. Its area is a pproximately $3,500 \mathrm{~km}^{2}$ and it has a total human population of approximately $6,000,000$. Total cattle population in Egypt is (4.950.000) [13]. The study started from June 2017 till August 2018.

Cross-sectional study was adopted; sampling collection was carried out by using stratified sampling technique. Four dairy farms with different levels of biosecurity measures (moderate to low) were selected for evaluating the epidemiological status of MRSA. To identify the potential risk factors for the prevalence of MRSA, questionnaires were used to gather information depending on observation, interviewing the dairy farmers and handlers and the field assessment of MRSA s tatus. Questions about animals and farm level factors as well as inquire educational needs of dairy fa rmers, a nimal level factors as general herd feature, herd size, breed, age, lactation phase, cow identification, individual milk production and whole milk yield were recorded. The farm level factors as housing type, bi os ecurity practices, milking system, ba rn floor bedding, dry cow therapy routines, mastitis handling record, treatment procedures of clinical ma stitis cases, therapy records, the use and regularity of microbiological cultures tests, milking sequences, the use and the frequency of antimicrobial susceptibility tests were also recorded [14]. Three breeds of dai ry cattl e included in this study (Holstein-Friesian, Simmental and local breeds). A total of 925 samples were collected from 4 selected dairy farms were chosen conveniently relied on dairy cow availability.

\subsection{California mastitis test (CMT)}

Astream of milkfrom each quarter of the udder was placed in each of four shallow cups in the CMT paddle and the same a mount of the reagent was added. A gentl e circular motion was done in a horizontal plane. Positive samples displayed gel formation within a few seconds. The result was scored based on the gel formation and considered as negative if there was no gel formation and recorded as zero, or positive if there was gel formation scoring from trace $(T)$ to +3 . If in a ny case one quarter was positive by the CMT then the cattle was considered positive [15].

\subsection{Sample collection}

A total of 925 samples were randomly collected from dairy cattle, 372 samples for ea ch of individual quarter's milk and 372 teat skin swabs. Samples of dairy cattle were collected from 4 different dairy farms. Each sample was labelled with the foll owing information; breed, age, lactation stage, pa rity, udder status and time of collection. In addition, a total of 181 different environmental samples were collected including BTM (37), milking linear (27), feed troughs (27), water troughs (27), bedding (36) and workers' nasal swabs (27).

\subsection{Culturing and identification}

For is olation and identification of $S$. aureus, a loopful of enriched samples was streaked onto selective media for Staphylococcus aureus (Baird-Parker agar, Oxiod, England). The typical colonies of Staphylococcus aureus are black, shiny, convex (2-4 mm size) with entire margins and clearzones, with an opaque precipitation zone after 48 hours. Pure isolated single colonies were picked up and sub-cultured on trypton soya broth (TSB) at $37^{\circ} \mathrm{C} / 24$ hours. Then, stored in buffered glycerol at $-20^{\circ} \mathrm{C}$ for further identification procedures [16]. The phenotypic identification of isolated Staphylococcus aureus was relied on colony morphology, gram staining and biochemical tests; positive catalase test and positive tube coagulase rabbit plasma test at 4 and $24 \mathrm{hrs}$. (Positive result is indicated by gelling of the plasma).

\subsection{Cefoxitin disk diffusion test}

Methicillin-resistance in Staphylococcus aureus was identified bycefoxitin screening. Disc diffusion test is employed by incubating Staphylococcus aureus on tryptone soya broth (TSB) impregnated with Cefoxitin $(30 \mu \mathrm{g})$ discs. MRSA is identified by assessing zone of inhibitions. The Staphylococaus aureus ca tegorized as methicillin-resistant, if showed inhibition di a meter zone $\leq 21 \mathrm{~mm}$. Cefoxitin induces mecAgene of MRSA and its results have been found in concordance to PCR. Thus, Cefoxitin disc diffusion test can be al ternative to PCR for the detection of MRSA in resource constraint settings [17].

\subsection{Statistical analysis}

Collected data was coded and entered to MS Excel spreadsheet and checked for accuracy. After validation, it was transferred and processed using computer software SPSS version 23 for a nalysis. Pearson's chi-square tests were used when appropriate to analyze the proportions of categorical data. 95\% Confidence Interval was computed and the results were considered significant at $\mathrm{P}<0.05$. 


\section{Results}

\subsection{Biosecurity status of the examined dairy farms throughout the study period.}

The ass umed score of biosecurity was examined in the four examined dairy farms based on the adopted biosecurity measures.

Table 1. The assumed scores of biosecurity level at the examined farms.

\begin{tabular}{|c|c|c|c|c|}
\hline Measures & $\begin{array}{l}\text { Farm } \\
\text { I }\end{array}$ & $\begin{array}{l}\text { Farm } \\
\text { II }\end{array}$ & $\begin{array}{l}\text { Farm } \\
\text { III }\end{array}$ & $\begin{array}{l}\text { Farm } \\
\text { IV }\end{array}$ \\
\hline $\begin{array}{l}\text { 1.Proper administration of } \\
\text { antibiotics (Under Veterinary } \\
\text { Supervision) }\end{array}$ & 1 & 0 & 0 & 0 \\
\hline $\begin{array}{l}\text { 2. Milking (Occurred under } \\
\text { hygienic procedure) }\end{array}$ & 1 & 0 & 1 & 0 \\
\hline $\begin{array}{l}\text { 3. Restrict Access of visitors and } \\
\text { vehicles. }\end{array}$ & 1 & 0 & 1 & 0 \\
\hline $\begin{array}{l}\text { 4. Personnel hygiene (wearing } \\
\text { coverall and boots) }\end{array}$ & 0 & 0 & 0 & 0 \\
\hline $\begin{array}{l}\text { 5.Farm biosecurity level } \\
\text { (acceptable biosecurity level) }\end{array}$ & 1 & 0 & 1 & 0 \\
\hline $\begin{array}{l}\text { 6. Routine screening of milk } \\
\text { (CMT) }\end{array}$ & 1 & 0 & 0 & 0 \\
\hline $\begin{array}{l}\text { 7.In vitro testing of antibiotic } \\
\text { before using it }\end{array}$ & 0 & 0 & 0 & 0 \\
\hline 8. wearing gloves during milking & 1 & 0 & 0 & 0 \\
\hline $\begin{array}{l}\text { 9.Fore-milking teat cleaning and } \\
\text { disinfection }\end{array}$ & 1 & 1 & 1 & 0 \\
\hline $\begin{array}{l}\text { 10. Prior-milking teat cleaning } \\
\text { and disinfection }\end{array}$ & 1 & 1 & 1 & 0 \\
\hline $\begin{array}{l}\text { 11.Record keeping about } \\
\text { antibiotic treatment }\end{array}$ & 1 & 0 & 0 & 0 \\
\hline $\begin{array}{l}\text { 12. Having plane for treating sick } \\
\text { animals with antibiotic }\end{array}$ & 1 & 1 & 1 & 0 \\
\hline $\begin{array}{l}\text { 13.After administration of } \\
\text { antibiotic, are the course of } \\
\text { treatment completed }\end{array}$ & 1 & 1 & 1 & 0 \\
\hline $\begin{array}{l}\text { 14. Treated cow marked as } \\
\text { treated }\end{array}$ & 1 & 1 & 1 & 0 \\
\hline $\begin{array}{l}\text { 15.Treated cow physically } \\
\text { separated from other milking } \\
\text { cows }\end{array}$ & 1 & 0 & 0 & 0 \\
\hline 16. Are treated cow Milked last & 1 & 1 & 1 & 0 \\
\hline $\begin{array}{l}\text { 17.Are treated cow milked with } \\
\text { separate milking unit }\end{array}$ & 0 & 0 & 0 & 0 \\
\hline $\begin{array}{l}\text { 18. Are cow routinely Screened } \\
\text { after antibiotic treatment by } \\
\text { antibiotic residue detect kit }\end{array}$ & 0 & 0 & 0 & 0 \\
\hline $\begin{array}{l}\text { 19. Milk Sampled for culture in } \\
\text { case of mastitis }\end{array}$ & 0 & 0 & 0 & 0 \\
\hline 20. Beeding routinely changed & 1 & 1 & 1 & 0 \\
\hline Assumed level & 1 & 0 & 1 & 0 \\
\hline
\end{tabular}

Moderate biosecurity=1; Low

biosecurity $=0$
Table 1 reveals that both farms I and III had a moderate biosecurity level (1); however, farms II and IV had the lowest level (0)

Table 2. Scoring system for biosecurity level in the examined farms.

\begin{tabular}{|c|c|c|}
\hline & Variable & Description and level \\
\hline 1 & $\begin{array}{l}\text { Proper administration of } \\
\text { antibiotics }\end{array}$ & $\begin{array}{l}\text { Under veterinary supervision }=1 \text {; } \\
\text { without supervision }=0\end{array}$ \\
\hline 2 & Milking & $\begin{array}{l}\text { Occurred under hygienic } \\
\text { procedure }=1 \text {; milking procedure } \\
\text { not hygienic }=0\end{array}$ \\
\hline 3 & $\begin{array}{l}\text { Restrict Access of visitors and } \\
\text { vehicles }\end{array}$ & Yes $=1 ; \mathrm{No}=0$ \\
\hline 4 & Personnel hygiene & $\begin{array}{l}\text { wearing coverall and boots }=1 \text {; not } \\
\text { wearing coverall and boots }=0\end{array}$ \\
\hline 5 & Farm biosecurity level & $\begin{array}{l}\text { acceptable biosecurity level=1; } \\
\text { poor biosecurity level=0 }\end{array}$ \\
\hline 6 & Routine screening of milk & $\begin{array}{l}\text { Regular California Mastitis testing } \\
(\mathrm{CMT})=1 \text {; not apply } \mathrm{CMT}=0\end{array}$ \\
\hline 7 & $\begin{array}{l}\text { In vitro testing of antibiotic } \\
\text { before using it }\end{array}$ & Yes $=1 ; \mathrm{No}=0$ \\
\hline 8 & wearing gloves during milking & Yes $=1 ; \mathrm{No}=0$ \\
\hline 9 & $\begin{array}{l}\text { Fore-milking teat cleaning and } \\
\text { disinfection }\end{array}$ & Yes $=1 ; \mathrm{No}=0$ \\
\hline 10 & $\begin{array}{l}\text { Prior-milking teat cleaning and } \\
\text { disinfection }\end{array}$ & Yes $=1 ; \mathrm{No}=0$ \\
\hline 11 & $\begin{array}{l}\text { Record keeping about } \\
\text { antibiotic treatment }\end{array}$ & Yes $=1 ; \mathrm{No}=0$ \\
\hline 12 & $\begin{array}{l}\text { Having plane for treating sick } \\
\text { animals with antibiotic }\end{array}$ & Yes $=1 ; \mathrm{No}=0$ \\
\hline 13 & $\begin{array}{l}\text { After administration of } \\
\text { antibiotic, are the course of } \\
\text { treatment completed }\end{array}$ & Yes $=1 ; \mathrm{No}=0$ \\
\hline 14 & $\begin{array}{l}\text { Treated cow marked as } \\
\text { treated }\end{array}$ & Yes $=1 ; \mathrm{No}=0$ \\
\hline 15 & $\begin{array}{l}\text { Treated cow physically } \\
\text { separated from other milking } \\
\text { cows }\end{array}$ & Yes $=1 ; \mathrm{No}=0$ \\
\hline 16 & Are treated cow Milked last & Yes $=1 ; \mathrm{No}=0$ \\
\hline 17 & $\begin{array}{l}\text { Are treated cow milked with } \\
\text { separate milking unit }\end{array}$ & Yes $=1 ; \mathrm{No}=0$ \\
\hline 18 & $\begin{array}{l}\text { Are cow routinely Screened } \\
\text { after antibiotic treatment by } \\
\text { antibiotic residue detect kit }\end{array}$ & Yes $=1 ; \mathrm{No}=0$ \\
\hline 19 & $\begin{array}{l}\text { Milk Sampled for culture in } \\
\text { case of mastitis }\end{array}$ & Yes $=1 ; \mathrm{No}=0$ \\
\hline 20 & Bedding routinely changed & Yes $=1 ; \mathrm{No}=0$ \\
\hline
\end{tabular}

\subsection{Prevalence of MRSA}

The results of MRSA prevalence in the examined dairy farms in relation to sample source are shown in table 3 , there is a significant difference at $P$ value $=0.000$ and $X_{2}=58.515$ for MRSA isolation rates from different sources. A total of 744 animal samples were examined during the study period, out of 
372 collected individual quarter milk samples, MRSA was isolated from 111 (29.8\%). Whereas, it was recovered at a rate of $41 \%$ from positive Staphylococcus aureus isolates. On the sa me time, out of 372 collected teat swab samples before and after iodine teat dipping, 26 (7 \%) is olates were identified as MRSA. It was noticed that all 26 positive detected MRSA from teat swabs were collected prior to dipping of teat by iodine.

Table 3. The prevalence of Methicillin-Resistance Staphylococcus aureus in relation to sample source (animal samples, workers and farm environment) in the examined dairy cattle farms at Dakahlia during (2017-2018).

\begin{tabular}{|c|c|c|c|c|c|}
\hline \multirow[t]{2}{*}{ Sample (No.) } & \multicolumn{2}{|c|}{$\begin{array}{l}\text { Distribution } \\
\text { of } S . \text { aureus } \\
(n=549)\end{array}$} & \multicolumn{3}{|c|}{$\begin{array}{l}\text { Distribution of MRSA } \\
(n=207)\end{array}$} \\
\hline & No & $\%$ & No. & $\begin{array}{l}\text { S. aureus } \\
(\%)\end{array}$ & $\begin{array}{l}\text { Total d } \\
\text { (\%) }\end{array}$ \\
\hline \multicolumn{6}{|l|}{ Animal $(n=744)$} \\
\hline Individual milk ( $\mathrm{n=372)}$ & $\begin{array}{l}27 \\
1\end{array}$ & 72.8 & 111 & 41 & 29.8 \\
\hline $\begin{array}{l}\text { Teat skin swabs } \\
(n=372)\end{array}$ & $\begin{array}{l}15 \\
9\end{array}$ & 42.7 & 26 & 16.6 & 7 \\
\hline \multicolumn{6}{|l|}{$\begin{array}{l}\text { Environmental samples } \\
(n=181)\end{array}$} \\
\hline Bedding ( $n=36)$ & 21 & 58.3 & 14 & 66.7 & 38.9 \\
\hline BTM (n=37) & 24 & 64.9 & 17 & 70.8 & 45.9 \\
\hline Feed $(n=27)$ & 18 & 66.7 & 10 & 55.6 & 37 \\
\hline Water $(n=27)$ & 18 & 66.7 & 11 & 61.1 & 40.7 \\
\hline $\begin{array}{l}\text { Milking linear } \\
(n=27)\end{array}$ & 19 & 70.3 & 12 & 63.2 & 44.3 \\
\hline $\begin{array}{l}\text { Workers nasal swab } \\
(n=27)\end{array}$ & 19 & 70.4 & 6 & 31.6 & 22.2 \\
\hline
\end{tabular}

As regards to the environmental samples, a total of 181 sa mples including; 36 bedding, 27 feed, 27 mil king linear, 37 BTM, 27 water and 27 nasal swabs were collected from the four examined farms as shown in table 3. Among the positive Staphylococcus aureus, MRSA was more prevalent in BTM followed by bedding, milking linear then water troughs $(70.8 \%$, $66.7 \%, 63.2 \%$ and $61.1 \%$, respectively), while it was less prevalent in feed troughs and nasal swabs (55.6\% and 31.6\%, res pectively). Mea nwhile, the positive MRSA among collected environmental samples was 70 (38.7 \%), while it was (58.8\%) out of 119 positive Staphylococcus aureus. The high percentage of positive MRSA samples among total collected environmental samples was from BTM followed by milking linear, water troughs then bedding $(45.9 \%, 44.3 \%, 40.7$ and $38.9 \%$ respectively), while the lowest percentage was obtained from feed troughs and nasal swabs ( $37 \%$ and $22.2 \%$, res pectively).

Table 4. Animal-level risk factors associated with the prevalence of MRSA causing mastitis.

\begin{tabular}{|c|c|c|c|c|c|}
\hline \multirow{3}{*}{ Risk factor } & \multirow{3}{*}{ Categories } & \multicolumn{3}{|c|}{ MRSA } & \multirow[b]{3}{*}{$P$ value } \\
\hline & & Collecti & & & \\
\hline & & samplé & No. & $\%$ & \\
\hline \multirow[t]{3}{*}{ Age } & Young ( $<5$ years) & 32 & 7 & 21.9 & \\
\hline & $\begin{array}{l}\text { Adults (5-8 } \\
\text { years) }\end{array}$ & 71 & 44 & 62 & \\
\hline & Old (>8 years) & 27 & 25 & 92.6 & 0.000 \\
\hline \multirow[t]{2}{*}{ Parity } & Primiparous & 20 & 3 & 15 & \\
\hline & Multiparous & 110 & 73 & 66.3 & 0.000 \\
\hline \multirow{2}{*}{$\begin{array}{l}\text { Lactation } \\
\text { stage }\end{array}$} & Early ( $<4$ month) & 72 & 43 & 60 & \\
\hline & Late (>4 month) & 58 & 33 & 56.8 & 0.754 \\
\hline \multirow[t]{3}{*}{ Breed } & Holstein Friesian & 90 & 59 & 65.6 & \\
\hline & Simmental & 10 & 6 & 60 & \\
\hline & $\begin{array}{l}\text { Local breed } \\
\text { (Baladi) }\end{array}$ & 30 & 11 & 36.7 & 0.021 \\
\hline \multirow[t]{3}{*}{ Herd size } & Large $(>=2000)$ & 57 & 45 & 78.9 & \\
\hline & $\begin{array}{l}\text { Medium (1000- } \\
\text { 2000) }\end{array}$ & 40 & 19 & 47.5 & \\
\hline & Small (200-1000) & 33 & 12 & 36 & 0.000 \\
\hline
\end{tabular}

3.3. Prevalence of MRSA in relation to clinical findings and results of CMT

According to cow level prevalence of MRSA in relation to CMT observation of tested individual milk samples, MRSA was is olated mostly from mastitic quarters followed by sub-clinically mastitic then healthy quarters a sillustrated in Fig. (1), there is a significant difference at $P$-value $=0.000$ and $X_{2}=31.146$ for MRSA isolation rate from normal, ma stitic and subclinical milk. Screening performed with CMT paddle resulting in categorizing tes ted quarters to following; 125 (33.6\%) healthy quarters, 114 (30.6\%) sub-clinically infected quarters and 133 (35.8\%) clinically infected quarters (Figure 1).

The distribution of MRSA in relation to sea sonal variations was showed in Figure 2, it was notable that there is no significant effect of sea son upon MRSA prevalence at $X_{2}=4.015$. MRSA was more prevalent in summer (42.4\%), followed by s pring, winter and autumn at rates of $37 \%, 36 \%$ and $33 \%$, res pectively.

The potential risk factors at animal level associated with mastitis caused by MRSA are mainly focusing on breed, age, parity, lactation stage and herd size as illustrated in table 4. Low 
prevalence of mastitis was recorded in local breeds at a rate of $36.7 \%$ (11/30), while it was significantly higher in HolsteinFriesian breed at a rate of $65.6 \%(59 / 60)$ and Simmental breed by $60 \%(6 / 10)$ at $P$-value $=0.021$ and $X_{2}=7.743$. Also, the as sociation between mastitis and age of cattle was significant at $\mathrm{P}$-value $=0.000$ and $\mathrm{X}_{2}=30.951$. Elder age was more susceptible to mastitis than young age, at which mastitis distribution was $21.9 \%(7 / 32)$ within young age (less than 5 years) group, $62 \%$ (44\71) among adult age (between 5 to 8 years) cows and $92.6 \%(25 \backslash 27)$ within old aged (more than 8 years) cows. The incidence of mastitis has significant association with parity at $P$-value $=0.000$ and $X_{2}=18.385$. Evidently, the occurrence of mastitis was greater in multiparous cows $(66.3 \%)$ than primiparous cows $(15 \%)$. In contrast, the association between mastitis and stage of lactation was insignificant statistically, where $60 \%(43 \backslash 72)$ was mastitic during early lactation phase, however $56.8 \%$ (33\58) infected by mastitis during late lactation phase, incidence of mastitis slightly higher during early lactation than late lactation stage. In addition, there is a significant association between herd size and occurrence of mastitis at $P$-value $=0.000$ and $X_{2}=18.466$. The highest prevalence of MRSA observed in large size herds followed by medium and small herds at rates of $78.9 \%, 47.5 \%$ and $36 \%$, respectively.

Table 5. Risk factors associated with the prevalence of MRSA causing mastitis depending on farm-biosecurity level.

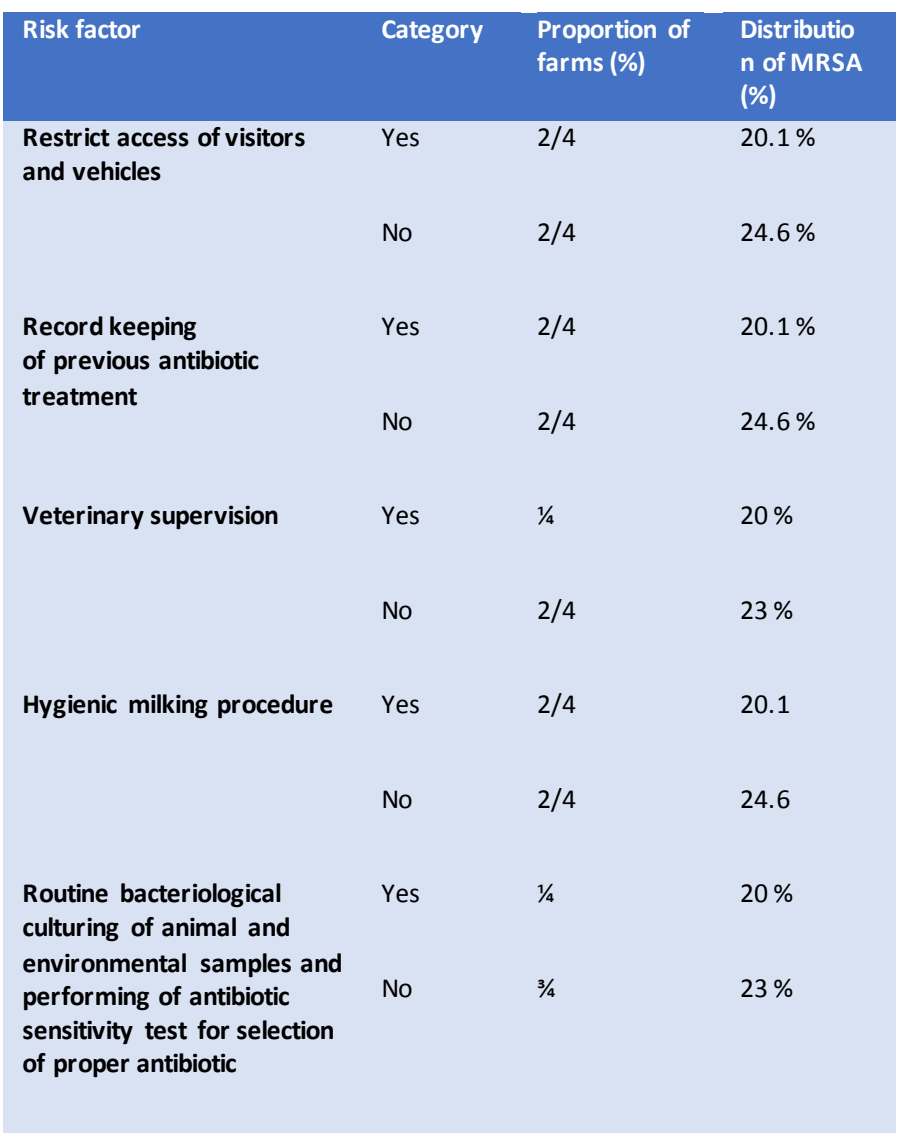

Our results investigated that farms which suffering from lack of biosecurity measures exhibited higher prevalence of MRSA, on the contrary, farms that adopt such measures showed lower prevalence of MRSA form collected samples. Farms that lack of keeping records of previous antibiotic treatment and also those do not have veterinary supervision inside farm s howed higher MRSA prevalence rates of $24.6 \%$ and $23 \%$, respectively. On the contrary, farms adopted aforementioned el ements of biosecurity mea sures, have lower rates $20.1 \%$ and $20 \%$ (Table 5 ).

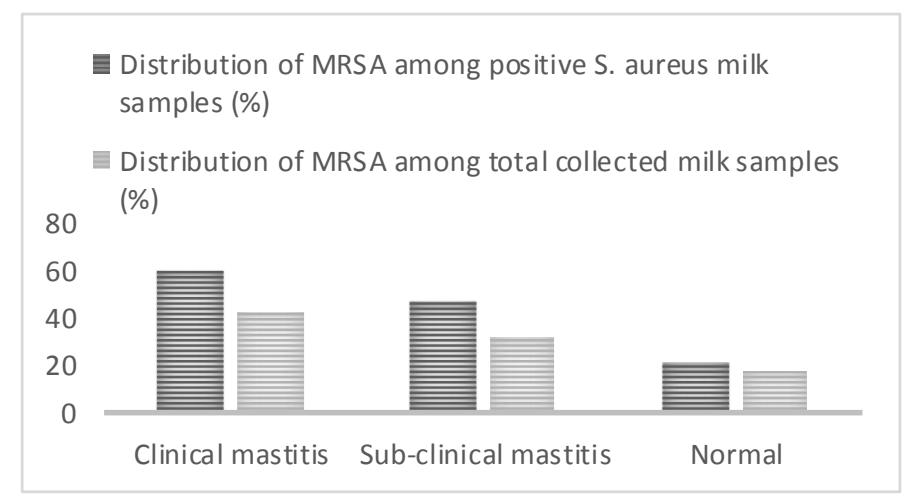

Figure 1..Prevalence of MRSA a ccording to CMT screening which reveal milk to 3 categories; normal, clinical mastitis and sub-clinical mastitis $(P$-value $=0.000)$.

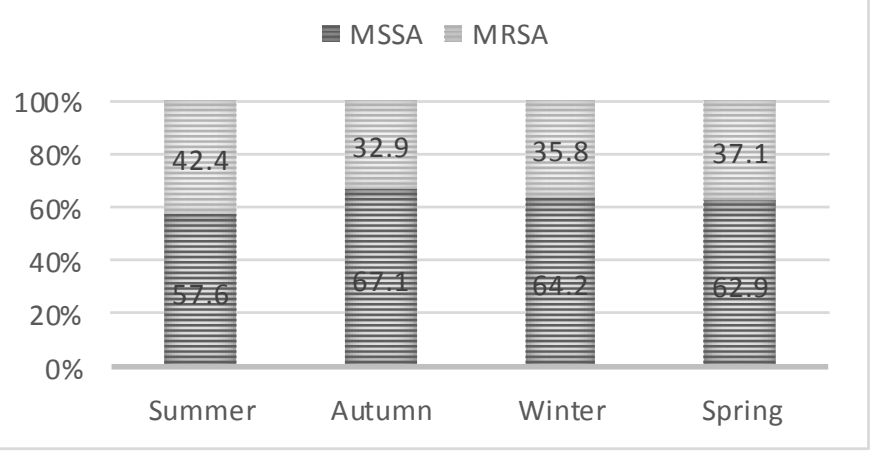

Figure 2. Prevalence of MSSA \& MRSA in relation to season in the examined dairy farms during 2017-2018.

\section{Discussion}

The prima ry aim of animal hygiene and adopted biosecurity plans is preventing disease before its incidence, as it is wellknown that an ounce of prevention is worth a pound of cure. Nowadays, MRSA has become reputable as a common problem in dairy farms with increasing frequency of their antimicrobial resistances. The study was conducted on large and middlesized dairy farms in and around Dakahlia governorate to determine the prevalence of mastitis and asses the major risk factors associated with MRSA. 
The appropriate levels of biosecu rity in the examined farms can be justified on the basis of increased risk of MRSA infection, irrespective of pathogenicity and in relation to applied biosecurity level. On this basis, farms I and III with the moderate level of biosecurity assumed to provide more than 50 $\%$ protection of disease occurrence with occasionally adopted biosecurity mea sures as lacking of personnel hygiene (wearing coverall and gl oves during milking), absence of prior in-vitro antibiotic tes ting, milking healthy and infected cows with the same unit, routine screening of antibiotic residues after trea tment by antibiotics and absence of milk samples culturing in case of mastitis to determine causative agent. However, farms possess level (0) of biosecurity corresponds to absence of most biosecurity measures had a higher risk of MRSA occurrence. The most detrimental factor of mastitis detection was the culturing of milk sample in case of mastitis and determination of the causative agent, then applying of antibiotic sensitivity test to choose the most effective antibiotic, in a ddition to the pres ence of veterinary supervision that regulate administration of antibiotics. It has been eluci dated that farms with a higher biosecurity score, giving concern to identify mastitis causative agents and selecting proper antibiotic to i nhibit it under strict veterinary supervision had higher prognosis and less MRSA prevalence. Our findings are in accordance with those found by $[12,18-20]$.

The variations in MRSA prevalence from variable sources may be due to the differences in animal-husbandry systems, breeds, antimicrobial policies and regulations which may contribute to the variety of prevalence estimates. Our data agreed with those reported by $[21,22]$.

For effective inhibition of intra-mammary infection (IMI), it is important to know the prevalence and distribution of its causative pathogens and the risk factors associated with the mastitis. The overall percentage of Staphylococcus aureus isolated from collected individual raw milk samples was $72.8 \%$; our res ults are nearly similar to those previously obtained by [1, $21,23]$ in Bangladesh, Brazil and South Africa. On the contrary, Staphylococcus aureus had lower prevalence rates; $41 \%, 11 \%$ and $5.5 \%$ from raw milk samples in studies conducted by [22, 24, 25], respectively.

The overall percentages of Staphylococcus aureus and MRSA from total collected animal and environmental samples were $59.4 \%$ and $22.4 \%$, respectively. Similarly, to these findings, [26] recovered Staphylococcus aureus at the rate of $58 \%$ form both types of samples, but found lower MRSA prevalence rate of $3 \%$.

The prevalence of MRSA from the total collected individual milk samples was $29.8 \%$. Our findings go in harmony with those of $[8,21,27,28]$ in Pakistan, Jordan, South Africa and Germany. Whi le, higher results were recorded by [29] who isolated MRSA from $60 \%$ of the examined individual milk samples. whereas, lower values of $3.7 \%$ were found by [30]. When we examined the preval ence of MRSA a mong positive Staphylococcus aureus, we investigated high rates at $41 \%$. These findings are significantly higher than those recorded by [31-35] who identified MRSA among Staphylococcus aureus isolates at the rates of $4 \%, 0 \%, 0.6 \%, 16.7 \%$ and $7.4 \%$, res pectively. Nearly similar results were also investigated by [36] in India and [37] who revealed MRSA with percentages of $29 \%$ and $31 \%$, respectively. Our mentioned data also supported by [38] results, who reported that MRSA is olated at the rate of $52 \%$ from recovered Staphylococcus aureus in Egypt. On the other hand, higher prevalence rates of $60 \%$ and $64.1 \%$ were recorded by $[12,25]$ in Ethiopia.

In addition, Staphylococcus aureus was isolated from $58 \%$ of bedding samples nearly agreed with [39] who reported that approximately half of bedding samples harbor Staphylococaus aureus. However, the overall percentage of MRSA isolated from bedding in the examined dairy farms was $38.9 \%$. Our findings go in harmony with [12] results, who attributed this level to poor hygienic muddy bedding which favor propagation and transmission of mastitis microbes.

Concerning to the presence of MRSA in the dairy farm environment, it was $38.7 \%$ from total collected environmental samples. These findings were markedly higher than records of [40] Who reported lower prevalence level (25\%) of MRSA. On the contrary, higher value of $46.7 \%$ was recorded by [41]. Among environmental samples, BTM was the main source of MRSA at the rate of $44 \%$. These results were closely similar to [29] findings, who isolated MRSA from $45 \%$ of tested BTM. But, we recorded higher levels than [42] who demonstrated $6.1 \%$ MRSA prevalence rate from environmental samples. Also, MRSA preval ence rate among different types of environmental samples, bedding harbored $38.9 \%$ positive MRSA. Lower results were reported by [41] who isolated MRSA at rate $19 \%$. Nearly similar to our findings of Staphylococcus aureus rates in teat swab samples (42.7\%), [39] was isolated Staphylococcus aureus from teat swabs at the rate of $(44 \%)$. Furthermore, with reference to the occurrence of Staphylococcus aureus and MRSA in milking linear, our findings are in a lignment with [39] who reported that Staphylococcus aureus milking linear isolates represent $62 \%$ of the total collected mil king li near samples. Farm workers represent possible source for MRSA transmission through dairy farm. Our findings demonstrated MRSA in (22.2\%) from total collected nasal swabs, similarly to the findings of [43] who recorded (23\%) positive MRSA from nasal swab samples.

The incidence of Staphylococcus aureus and MRSA in relation to the CMT was investigated, where within the total screened quarters, MRSA found more prevalent in mastitic milk at a rate of $41.4 \%$ followed by sub-clinically infected quarters $31.6 \%$, then healthy quarters at a rate of $17.6 \%$. Meanwhile, MRSA distribution a mong total positive Staphylococcus aureus from screened quarters, was highly prevalent from mastitic 
quarters at the rate of $59.8 \%$ followed by sub-clinicallymastitic quarters at the rate of $46.2 \%$ with the lowest prevalence rate from heal thy quarters at rate of (21.2\%). Our findings go in line with $[12,18]$ who indicated that pathogen was mostly as sociated with clinical mastitis. Whereas, the current data was higher than those recorded by [44] who reported that MRSA present in subclinical mastitic milk at percent of $5.9 \%$. On the other hand, $[43,45,46]$ revealed lower prevalence rates of MRSA from positive Staphylococcus aureus in comparing with our findings from mastitic milk as following; $12 \%, 17.2 \%$ and $4.4 \%$, res pectively. I n contrast to our findings, $[47,48]$ reported that MRSA was more prevalent in sub-clinical mastitic milk than clinically mastitic milk. Regarding to the prevalence of Staphylococcus aureus within mastitic milk, our findings are in accordance with [39], but it was higher when compared to [27] findings, who found that the prevalence of Staphylococaus aureus was (28\%), among them (28.57\%) MRSA was detected.

MRSA incidence in relation to the seasonal changes was studied, where it was more prevalent in summer (42.4\%), followed by spring, winter and autumn at rates of $37 \%, 36 \%$ and $33 \%$, respectively. The seasonal variations could be attributed to the effect of climatic variations; temperature, humidity and rainfall rate in between sea sons, bes ides higher udder hygiene was a dopted during winter, where the lactation process mostly take place during this season. These results are similar to those found by $[49,50]$ who stated that Season possess little significant in MRSA incidence.

Risk factors for the occurrence of mastitis were inves tigated in the examined farms, where according to our data low prevalence of mastitis was recorded in local breeds, vers us Holstein-Friesian breed at rate and Simmental breed. This variation could be attributed to the differences in anatomical and physiological features of mammary gland, in addition to genetic differences between breeds. The as sociation between mastitis and age of cattle was remarkable. Elder age was more susceptible to mastitis tha nyoung age. The incidence of mastitis has significant association with parity. However, the association between mastitis and stage of lactation was less significant. In addition, there is a significant as sociation between herd size and incidence of mastitis caused by MRSA. To elaborate, it was observed that large herd size characterized by increased stocking density and so higher risk of exposure to infections. The current study revealed that cows' breed, parity, age and herd size were the most detrimental risk factors associated with mastitisonset. Our findings agreed with those reported by $[11,12,51-55]$. Even though, findings of [18] conveyed no significant association between MRSA incidence and cows' breeds. Differences in the prevalence rates of mastitis from va rious findings could be due to variation in farm management practices, breeds of targeted cows, rate of production and variations in the study methods and materials employed by the investigators. Based on the observations made throughout the collection of samples, inadequate hygiene and deprived farm management practices contributed to the high incidence rates of MRSA mastitis. Where, MRSA is a contagious pathogen which can spread from a nimal to animal or personnel by contact with cows during unhygienic milking practice. The increased prevalence of Staphylococcus aureus in older animals in this study can be attributed to increased susceptibility of pathogenic organisms in udder relaxed sphincter muscles of teats.

Moreover, the risk factors associated with the prevalence of MRSA causing mastitis depending on farm-biosecurity level was el a borated in this study. The studied biosecuritymeasures affecting MRSA prevalence were; res trict access of visitors and vehicles; record keeping of previous antibiotic treatment; veterinary supervision; hygienic milking procedure; routine bacteriological culturing of animal and environmental samples; and performing of antibiotic sensitivity test for selection of proper antibiotic. Our results investigated that farms which suffering from lack of biosecurity measures exhibited higher prevalence of MRSA, on the contrary, farms that adopt such measures showed lower prevalence of MRSA form collected samples. Farms that lack of keeping records of previous antibiotic treatment and also those do not have veterinary supervision inside farm showed higher prevalence rates. On the contrary, farms adopt both types of biosecurity measures, have lower rates. These results a re similar to findings of [56-58], where authors confirmed that lack of pre and post dipping measures, udder towels used frequently on more than one cow, and not routinely use the gloves are the main factors associated with the high incidence of MRSA within the dairy farms.

\section{Conclusion}

For the development of effective MRSA prevention strategies, it is necessary to know which factors increase the risk for MRSA transmission into and within dairy herds. The risk factors for of MRSA into dairy herds are el der ages, multiparous cattle, and foreign breeds.

\section{Research Ethics Committee permission}

The current research work was permitted to be executed according to Standards of Res earch Ethics Committee, Faculty of Veterinary Medicine, Mansoura University.

\section{Conflict of interest}

The authors declare that they have no conflict of interest.

\section{Authors' contribution}

All authors had contributed equally.

\section{REFERENCES}

[1] Hoque MN, Das ZC, Rahman ANMA, Haider MG, Islam MA. Molecular characterization of Staphylococcus aureus strains in bovine mastitis milk in Bangladesh. Int J Vet Sci Med 2018 https://doi.org/10.1016/j.ijvsm.2018.03.008 
[2] Jamali H, Paydar M, Radmehr B, Ismail S, Dadrasnia A. Prevalence and antimicrobial resistance of Staphylococcus aureus isolated from raw milk and dairy products. Food Control 2015;54:383-8. https://doi.org/10.1016/j.foodcont.2015.02.013

[3] Zakary EM, Nassif MZ, Mohammed GM. Detection of Staphylococcus aureus in bovine milk and its product by real time PCR assay. GJBBR 2011;6:171-77.

[4] van Soest FJ, Santman-Berends IM, Lam TJ, Hogeveen H. Failure and preventive costs of mastitis on Dutch dairy farms. J Dairy Sci 2016;99:836574. https://doi. org/10.3168/jds.2015-10561

[5] Bueno I, Williams-Nguyen J, Hwang H, Sargeant JM, Nault AJ, Singer RS. Systematic Review: Impact of point sources on antibiotic-resistant bacteria in the natural environment. Zoonoses Public Health. 2018;65:e162-e84. https://doi.org/10.1111/zph.12426

[6] Rollin E, Dhuyvetter K, Overton M. The cost of clinical mastitis in the first 30 days of lactation: An economic modeling tool. Prev Vet Med 2015;122:257-64. https://doi.org/10.1016/j.prevetmed.2015.11.006

[7] Klibi A, Jouini A, Gomez P, Slimene K, Ceballos S, Torres C, et al. Molecular Characterization and Clonal Diversity of Methicillin-Resistant and Susceptible Staphylococcus aureus Isolates of Milk of Cows with Clinical Mastitis in Tunisia. Microb Drug Resist 2018. https://doi.org/10.1089/mdr. 2017.0278

[8] Obaidat MM, Bani Salman AE, Roess AA. High prevalence and antimicrobia I resistance of mecA Staphylococcus aureus in dairy cattle, sheep, and goat bulk tank milk in Jordan. Trop Anim Health Prod 2017. https://doi.org/10.1007/s11250-017-1449-7

[9] Manyi-Loh C, Mamphweli S, Meyer E, Okoh A. Antibiotic Use in Agriculture and Its Consequential Resistance in Environmental Sources: Potential Public Health Implications. Molecules. 2018;23. https://doi.org/10.3390/molecules23040795

[10]Teng F, Wang X, Li T, Liu S, Wan C, Li X, et al. Clinical Mastitis Caused by Methicillin-resistant Staphylococcus aureus in a Heifer. Asian J Adv Agric Res 2017;4:1-5. https://doi.org/10.9734/AJAAR/2017/37289

[11]Abera M, Demie B, Aragaw K, Regassa F, Regassa A. Isolation and identification of Staphylococcus aureus from bovine mastitic milk and their drug resistance patterns in Adama town, Ethiopia. J Vet Med Anim Health 2010;2:29-34

[12]Tassew A. Isolation, Identification and Antimicrobial Resistance Profile of Staphylococcus aureus and Occurrence of Methicillin Resistant S. aureus Isolated from Mastitic Lactating Cows in and around Assosa Town, Benishangul Gumuz Region, Ethiopia. J Dairy Vet Anim Res 2017;6. https://doi.org/10.15406/jdvar.2017.06.00180

[13] Gennari P, Heyman A, Kainu M. FAO Statistical Pocketbook. World food and agriculture. Food and Agriculture Organization of the United Nations, Rome, Italy. 2015.

[14] da Costa LB. Epidemiology, Genetic and Molecular Characterization of Staphylococcus aureus in Ohio Dairy Farms: The Ohio State University; 2014.

[15] Quinn P, Markey B, Carter M, Donnelly W, Leonard F. Veterinary Microbiology and Microbial Disease. First Published Blackwell Science Company, lowa. State University Press; 2002.

[16] Kanaan MHG, AL-Shammary AHA. Detection of methicillin or multidrug resistant Staphylococcus aureus (MRSA) in locally produced raw milk and soft cheese in Baghdad markets. Iraqi J Vet.2013;37:226-31.

[17] Locatelli C, Cremonesi P, Caprioli A, Carfora V, Ianzano A, Barberio A, et al. Occurrence of methicillin-resistant Staphylococcus aureus in dairy cattle herds, related swine farms, and humans in contact with herds. J Dairy Sci 2017;100(1):608-19. https://doi. org/10.3168/jds.2016-11797

[18] Asmelash T, Mesfin N, Addisu D, Aklilu F, Biruk T, Tesfaye S. Isolation, identification and drug resistance patterns of methicillin resistant Staphylococcus aureus from mastitic cows milk from selected dairy farms in and around Kombolcha, Ethiopia. J Vet Med Anim Health. 2016;8:1-10. https://doi.org/10.5897/JVMAH2015.0422

[19] Ruegg P. Management of mastitis on organic and conventional dairy farms. J Anim Sci. 2009;87:43-55. https://doi. org/10.2527/jas.2008-1217

[20] Dufour S, Barkema HW, DesCôteaux L, DeVries TJ, Dohoo IR, Reyher K, et al. Development and validation of a bilingual questionnaire for measuring udder health related management practices on dairy farms. Prev Vet Med 2010;95(1-2):74-85. https://doi. org/10.1016/j. prevetmed.2010.02.018

[21] Akindolire MA, Babalola OO, Ateba CN. Detection of Antibiotic Resistant Staphylococcus aureus from Milk: A Public Health Implication. Int J Environ Res Public Health 2015;12(9):10254-75. https://doi. org/10.3390/ijerph120910254

[22] Lee SH, Camargo CH, Goncalves JL, Cruz AG, Sartori BT, Machado MB, et al. Characterization of Staphylococcus aureus isolates in milk and the milking environment from small-scale dairy farms of Sao Paulo, Brazil, using pulsed-field gel electrophoresis. J Dairy Sci. 2012;95(12):7377-83. https://doi.org/10.3168/jds.2012-5733

[23] de Oliveira LP, e Barros LSS, Carneiro Silva V, Cirqueira MG. Study of Staphylococcus aureus in raw and pasteurized milk consumed in the Reconcavo area of the State of Bahia, Brazil. J Food Process Technol 2011;02(06). https://doi.org/10.4172/2157-7110.1000128

[24] Mohammed J, Ziwa MH, Hounmanou YMG, Kisanga A, Tuntufye HN. Molecular Typing and Antimicrobial Susceptibility of Methicillin-Resistant Staphylococcus aureus Isolated from Bovine Milk in Tanzania. Int J Microbiol 2018;2018:1-6. https://doi.org/10.1155/2018/4287431

[25] Daka D, Yihdego D. Antibiotic-resistance Staphylococcus aureus isolated from cow's milk in the Hawassa area, South Ethiopia. Ann Clin Microbiol Antimicrob 2012;11:26. https://doi.org/10.1186/1476-0711-11-26

[26] Papadopoulos P, Papadopoulos T, Angelidis AS, Boukouvala E, Zdragas A, Papa A, et al. Prevalence of Staphylococcus aureus and of methicillinresistant S. aureus (MRSA) along the production chain of dairy products in north-western Greece. Food Microbiol 2018;69:43-50. https://doi.org/10.1016/j.fm.2017.07.016

[27] Nazir N, Wani SA, Nyrah Q, Farooq S, Hassan MN, Kashoo ZA. Virulence gene profile and antimicrobial resistance of Staphylococcus aureus isolated from bovine mastitis in Kashmir, India. J Nat Appl Sci 2017;9:8938. https://doi.org/10.31018/jans.v9i2.1294

[28] Feßler AT, Kadlec K, Hassel M, Hauschild T, Eidam C, Ehricht R, et al. Characterization of methicillin-resistant Staphylococcus aureus isolates from food and food products of poultry origin in Germany. Appl Environ Microbiol. 2011;77:7151-7. https://doi.org/10.1128/AEM.00561-11

[29] Antoci E, Pinzone MR, Nunnari G, Stefani S, Cacopardo B. Prevalence and molecular characteristics of methicillin-resistant Staphylococcus aureus (MRSA) among subjects working on bovine dairy farms. Infez Med 2013;21:125-9.

[30] Ismail ZB. Molecular characteristics, antibiogram and prevalence of multidrug resistant Staphylococcus aureus (MDRSA) isolated from milk obtained from culled dairy cows and from cows with acute clinical mastitis. Asian Pac J Trop Biomed 2017;7:694-7. https://doi.org/10.1016/j.apjtb.2017.07.005

[31] Haran KP, Godden SM, Boxrud D, Jawahir S, Bender JB, Sreevatsan S. Prevalence and characterization of Staphylococcus aureus, including methicillin-resistant Staphylococcus aureus, isolated from bulk tank milk from Minnesota dairy farms. J Clin Microbiol. 2012;50:688-95. https://doi.org/10.1128/JCM.05214-11

[32] Anderson K, Lyman R, Moury K, Ray D, Watson D, Correa M. Molecular epidemiology of Staphylococcus aureus mastitis in dairy heifers. J Dairy Sci 2012;95:4921-30. https://doi.org/10.3168/jds. 2011-4913

[33] Wagner S, Erskine R. Antimicrobial drug use in mastitis. Antimicrobial Therapy in Veterinary Medicine, Fifth Edition. 2013:519-28. https://doi.org/10.1002/9781118675014.ch30

[34] Spohr M, Rau J, Friedrich A, Klittich G, Fetsch A, Guerra B, et al. Methicillinresistant Staphylococcus aureus (MRSA) in three dairy herds in southwest Germany. Zoonoses Public Health. 2011;58:252-61. https://doi.org/10.1111/j.1863-2378.2010.01344.x

[35] Rai A, Tiwari HK. Prevalence and Antimicrobial Resistance of Methicillin Resistant Staphylococcus aureus (MRSA) in Cow Milk from Gangtok, East Sikkim. 2016.

[36] Graveland H, Wagenaar JA, Heesterbeek H, Mevius D, van Duijkeren E, Heederik D. Methicillin resistant Staphylococcus aureus ST398 in veal calf farming: human MRSA carriage related with animal antimicrobial usage and farm hygiene. PLoS One. 2010;5:e10990. https://doi.org/10.1371/journal. pone.0010990 
[37] Pehlivanoğlu F, Yardımcı H. Detection of methicillin and vancomycin resistance in Staphylococcus strains isolated from bovine milk samples with mastitis. Kafkas Üniversitesi Veteriner Fakültesi Dergisi 2012; 18: 849-855. https://doi.org/10.9775/kvfd. 2012.6642

[38] Falagas ME, Karageorgopoulos DE, Leptidis J, Korbila IP. MRSA in Africa: filling the global map of antimicrobial resistance. PLoS One 2013;8:e68024. https://doi.org/10.1371/journal. pone.0068024

[39] Gandhale D, Kolhe R, Nalband S, Deshpande P, Jagtap U, Dhandore C, et al. Molecular types and antimicrobial resistance profile of Staphylococcus aureus isolated from dairy cows and farm environments. Turk J Vet Anim Sci. 2017;41:713-24. https://doi.org/10.3906/vet-1703-50

[40] Lim S-K, Nam H-M, Jang G-C, Lee H-S, Jung S-C, Kim T-S. Transmission and persistence of methicillin-resistant Staphylococcus aureus in milk, environment, and workers in dairy cattle farms. Foodborne Pathog Dis 2013;10(8):731-6. https://doi.org/10.1089/fpd.2012.1436

[41] Ganai AW, Kotwal SK, Malik MA, Sharma HK, Wani N, Jeelani R. Prevalence ofStaphylococcus aureusand Methicillin ResistantStaphylococcus aureus(MRSA) in Clinical Setting and Dairy Farm Environment of Jammu. J Anim Res 2015;5:539. https://doi.org/10.5958/2277-940X.2015.00091.1

[42] Vyletelova M, VlkoVá H, Manga I. Occurrence and characteristics of methicillin resistant Staphylococcus aureus and methicillin resistant coagulase-negative staphylococci in raw milk manufacturing. Czech J Food Sci 2011;29:11-6. https://doi. org/10.17221/4443-CJFS

[43] Bardiau M, Yamazaki K, Duprez JN, Taminiau B, Mainil JG, Ote I. Genotypic and phenotypic characterization of methicillin-resistant Staphylococcus aureus (MRSA) isolated from milk of bovine mastitis. Lett Appl Microbiol 2013;57:181-6. https://doi.org/10.1111/lam.12099

[44] Zutic M, Cirkovic I, Pavlovic L, Zutic J, Asanin J, Radanovic O, et al. Occurrence of methicillin-resistant Staphylococcus aureus in milk samples from Serbian cows with subclinical mastitis. Afr J Microbiol Res 2012;6:5887-9. https://doi.org/10.5897/AJMR12.692

[45] Guimaraes FF, Manzi MP, Joaquim SF, Richini-Pereira VB, Langoni H. Short communication: Outbreak of methicillin-resistant Staphylococcus aureus (MRSA)-associated mastitis in a closed dairy herd. J Dairy Sci 2017;100(1):726-30. https://doi.org/10.3168/jds.2016-11700

[46] Turkyilmaz S, Tekbiyik S, Oryasin E, Bozdogan B. Molecular epidemiology and antimicrobial resistance mechanisms of methicillin-resistant Staphylococcus aureus isolated from bovine milk. Zoonoses Public Health. 2010;57:197-203. https://doi. org/10.1111/j.1863-2378.2009.01257.x

[47] Vanderhaeghen W, Cerpentier T, Adriaensen C, Vicca J, Hermans K, Butaye P. Methicillin-resistant Staphylococcus aureus (MRSA) ST398 associated with clinical and subclinical mastitis in Belgian cows. Vet Microbiol. 2010;144:166-71. https://doi. org/10.1016/j.vetmic.2009.12.044

[48] Gindonis V, Taponen S, Myllyniemi A-L, Pyörälä S, Nykäsenoja S, Salmenlinna $S$, et al. Occurrence and characterization of methicillinresistant staphylococci from bovine mastitis milk samples in Finland. Acta Vet Scand 2013;55:61. https://doi.org/10.1186/1751-0147-55-61

[49] Barkema H, Green M, Bradley A, Zadoks R. Invited review: The role of contagious disease in udder health. J Dairy Sci. 2009;92:4717-29. https://doi.org/10.3168/jds.2009-2347 pathogens in milk and the dairy farm environment: food safety and public

[50] Oliver SP, Jayarao BM, Almeida RA. Foodborne health implications. Foodborne Pathog Dis 2005;2:115-29. https://doi. org/10.1089/fpd.2005.2.115

[51] Haftu R, Taddele H, Gugsa G, Kalayou S. Prevalence, bacterial causes, and antimicrobial susceptibility profile of mastitis isolates from cows in largescale dairy farms of Northern Ethiopia. Trop Anim Health Prod 2012;44:1765-71. https://doi.org/10.1007/s11250-012-0135-z

[52] Bitew M, Tafere A, Tolosa T. Study on bovine mastitis in dairy farms of Bahir Dar and its environs. J Anim Vet Adv 2010;9:2912-7. https://doi.org/10.3923/javaa.2010.2912.2917

[53] Tenhagen B-A, Alt K, Pfefferkorn B, Wiehle L, Käsbohrer A, Fetsch A. Methicillin-resistant Staphylococcus aureus in conventional and organic dairy herds in Germany. J Dairy Sci 2018;101:3380-6. https://doi.org/10.3168/jds.2017-12939
[54] Barkema H, Schukken Y, Zadoks R. Invited review: The role of cow, pathogen, and treatment regimen in the therapeutic success of bovine Staphylococcus aureus mastitis. J Dairy Sci 2006;89:1877-95. https://doi.org/10.3168/jds. S0022-0302(06)72256-1

[55] Middleton J, Fox L, Gay J, Tyler J, Besser T. Use of pulsed-field gel electrophoresis for detecting differences in Staphylococcus aureus strain populations between dairy herds with different cattle importation practices. Epidemiol Infect 2002;129:387-95. https://doi.org/10.1017/S095026880200746X

[56] Dufour S, Dohoo I, Barkema H, DesCôteaux L, DeVries T, Reyher K, et al. Manageable risk factors associated with the lactational incidence, elimination, and prevalence of Staphylococcus aureus intramammary infections in dairy cows. J Dairy Sci 2012;95:1283-300. https://doi.org/10.3168/jds.2011-4711

[57] Guimarães F, Manzi M, Joaquim S, Richini-Pereira V, Langoni H. Outbreak of methicillin-resistant Staphylococcus aureus (MRSA)-associated mastitis in a closed dairy herd. J Dairy Sci 2017;100:726-30. https://doi.org/10.3168/jds.2016-11700

[58] Berchtold B, Bodmer M, van den Borne BH, Reist M, Graber HU, Steiner A, et al. Genotype-specific risk factors for Staphylococcus aureus in Swiss dairy herds with an elevated yield-corrected herd somatic cell count. J Dairy Sci 2014;97:4886-96. https://doi.org/10.3168/jds.2013-7760 